\title{
Brazilian Journal of Chemical

\section{EFFECT OF MIXING MODE ON THE BEHAVIOR OF AN ASBBR WITH IMMOBILIZED BIOMASS IN THE TREATMENT OF CHEESE WHEY}

\author{
L. H. S. Damasceno ${ }^{1}$, José A. D. Rodrigues ${ }^{2 *}$, S. M. Ratusznei ${ }^{2}$, M. Zaiat ${ }^{1}$ and E. Foresti ${ }^{1}$ \\ ${ }^{1}$ Departamento de Hidráulica e Saneamento, Escola de Engenharia de São Carlos, Universidade de São Paulo (USP), \\ Av. Trabalhador São Carlense 400, CEP: 13566-590, São Carlos - SP, Brazil. \\ ${ }^{2}$ Departamento de Engenharia Química e de Alimentos, Escola de Engenharia Mauá, Instituto Mauá de Tecnologia, \\ Praça Mauá 1, CEP: 09580-900, São Caetano do Sul - SP, Brazil. \\ E-mail: rodrigues@maua.br
}

(Received: August 14, 2006 ; Accepted: January 14, 2007)

\begin{abstract}
A hydrodynamic study of a mechanically stirred anaerobic sequencing batch biofilm reactor (ASBBR) containing immobilized biomass on polyurethane foam was performed with the aim to determine homogeneity of the reactor based on total mixing time. Turbine or helix propellers were used for stirring at rotor speeds of 100, 200, 300 and $500 \mathrm{rpm}$. Experimental values obtained were fitted to a Boltzmann sigmoid. Homogenization times of the reactor were negligible when compared to the 8-h cycle time for all conditions studied. At low propeller rotations the turbine propeller showed the best performance. For higher rotations total mixing times were similar for both propellers; however the helix propeller had better homogeneity conditions. At a subsequent stage the system was operated in batch mode treating cheese whey at concentrations of 500, 1000 and $2000 \mathrm{mgCOD} / \mathrm{L}$ and rotations of 200, 300 and $500 \mathrm{rpm}$. In these assays the importance of the propeller became evident not only for mixing, but also for substrate flow across the bed containing immobilized biomass. Due to axial flow, the helix propeller offered better mass transfer conditions, evidenced by improved organic matter conversion and lower production of total volatile acids. Keywords: ASBBR; Stirring; Mixing time; Cheese whey.
\end{abstract}

\section{INTRODUCTION}

Anaerobic sequencing batch reactors (ASBRs) have been studied for treatment of high-strength wastewaters (dairy, piggery and landfill leachate) as well as low-strength ones (domestic wastewater). Although investigations focus more on bench-scale reactors, results presented are promising, showing the real potential of these systems as an alternative to continuous ones. Operation principles of an ASBR are extremely simple. Treatment takes place in a single tank and a typical cycle consists of four steps: feeding, reaction, decanting and discharge (Dague et al., 1992).
Stirring has an important role during the reaction step. It provides close contact between the substrate and the biomass, thus being one of the advantages of the ASBR, as it does not require complex feed systems. To provide mixing in the reactor, either mechanical stirring (continuous or intermittent) or gas or liquid circulation may be used (Angenent \& Dague, 1995; Ndon \& Dague, 1997; Zaiat et al., 2001).

Adopting a system with immobilized biomass allows the creation of alternatives to circumvent problems encountered in other systems, such as the uncertainty of granulation and elimination of the decanting step. The latter advantage becomes competitive, since the decanting time may be longer

*To whom correspondence should be addressed 
than $25 \%$ of the total cycle time (Droste \& Massé, 1995; Zhang et al., 1996; Dugba \& Zhang, 1999). On the other hand, when immobilized biomass is used the effect of mass transfer should also be taken into account.

Biomass immobilization on polyurethane foam in mechanically stirred ASBRs was proposed by Ratusznei et al. (2000). In the system used the reactor maintained homogeneity by stirring with a magnetic stirrer operated at $500 \mathrm{rpm}$. Biomass was immobilized in $0.5 \mathrm{~cm}$ polyurethane foam cubes inside a basket inside the reactor. Employing the same reactor the authors studied the effect of stirring on reactor performance (Ratusznei et al., 2001) and observed an increase in COD organic matter conversion with increasing rotor speed. In order to assess the effects of solid-phase mass transfer on the performance of an ASBBR containing immobilized biomass, Cubas et al. (2002) evaluated different polyurethane-foam cube sizes in treating complex low-strength wastewater. Solid-phase mass transfer was seen not to be the limiting step in organic matter conversion for particles between 0.5 and $2.0 \mathrm{~cm}$. Only $3.0 \mathrm{~cm}$ particles showed solid-phase mass transfer resistance. Pinho et al. (2002) applied different rotations $(500,700,900$ and $1100 \mathrm{rpm})$ to determine the influence of stirring frequency in the treatment of partially soluble effluents in an ASBR containing immobilized biomass on $3 \mathrm{~cm}$ polyurethane foam cubes. The residual substrate concentration was seen to decrease with increasing stirring frequency, improving treated effluent conditions.

Within this context, the main objective of this research was to assess mixing conditions and their relation to performance in organic matter conversion in an ASBBR containing immobilized biomass applied to the treatment of cheese whey.

\section{MATERIALS AND METHODS}

The reactor used was made of acrylic with a diameter and a height of $20 \mathrm{~cm}$ and a total volume of $6 \mathrm{~L}$. A $10 \mathrm{~cm}$ high basket was used in the reactor to contain $0.5 \mathrm{~cm}$ polyurethane foam cubes. This basket occupied half of the reactor volume to allow permanent immersion of the bed during the operation. This configuration was based on that proposed by Ratusznei et al. (2000) where the basket occupied the whole reactor volume. Stirring was provided by either a turbine or two helix propellers. The turbine propeller with a diameter of $6 \mathrm{~cm}$ had six vertical flat blades and was positioned below the bed at a clearance of $3 \mathrm{~cm}$ from the reactor bottom. The helix propellers with a diameter of $6 \mathrm{~cm}$ consisted of three blades; one was positioned $2 \mathrm{~cm}$ from the reactor bottom and the other above the bed, $12 \mathrm{~cm}$ from the reactor bottom. A scheme of the reactor setup is presented in Figure 1.

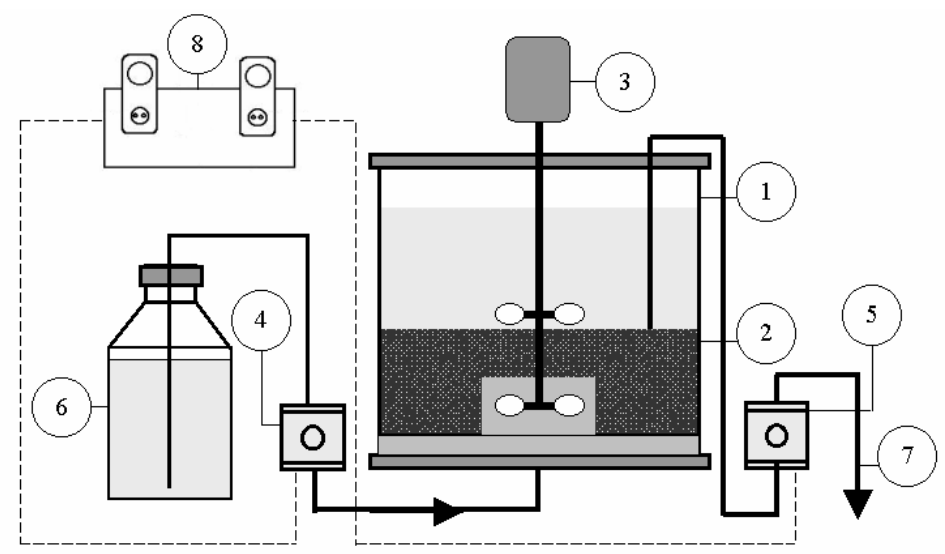

1. reaction tank;

2. stainless steel basket containing particles with immobilized cells;

3. mechanical stirrer;

4. feed pump;

5. discharge pump;

6. substrate,

7. treated effluent;

8. timers.

Figure 1: Scheme of the anaerobic sequencing batch reactor containing immobilized biomass

The hydrodynamic assays were performed using the stimulus and response technique to determine the degree of homogeneity in the reactor, thereby characterizing the stirring by total mixing time. To estimate total mixing time a pulse-type stimulus was used by adding $5 \mathrm{~mL}$ of $0.5 \mathrm{~N} \mathrm{H}_{2} \mathrm{SO}_{4}$ and the response was accompanied by monitoring $\mathrm{pH}$. It was assumed that the pHmeter electrode had a quick response (measured delay time of $8.0 \mathrm{~s}$ ) with a negligible lag in relation to process time. After injection, no immediate variation in $\mathrm{pH}$ was observed, causing a lag time $\left(\mathrm{t}_{0}\right)$ defined as the time 
between acid solution injection into the system and detection by the electrode of the $\mathrm{pH}$ meter.

To determine mixing time $\left(\mathrm{t}_{\text {mix }}\right)$, variation in $\mathrm{pH}$ in the system was assumed to have a Boltzmann sigmoid behavior, as shown in Equation (1), where y represents $\mathrm{pH}$ value, $\mathrm{A}_{1}$ initial y value $(\mathrm{y}(-\infty)), \mathrm{A}_{2}$ final $\mathrm{y}$ value $(\mathrm{y}(+\infty)), \mathrm{x}$ the time elapsed, $\mathrm{x}_{0}$ the $\mathrm{x}$ value corresponding to halfway between $A_{1}$ and $A_{2}$ $\left(y\left(x_{0}\right)=\left(A_{1}+A_{2}\right) / 2\right)$ and $d x$ the size of the value span in $\mathrm{x}$ that has the largest variation in $\mathrm{y}$.

$\mathrm{y}=\frac{\mathrm{A}_{1}-\mathrm{A}_{2}}{1+\mathrm{e}^{\left(\mathrm{x}-\mathrm{x}_{0}\right) / \mathrm{dx}}}+\mathrm{A}_{2}$

Assuming mixing time $\left(t_{\text {mix }}\right)$ to be the time necessary for the $\left(A_{1}-y\right) /\left(A_{1}-A_{2}\right)$ ratio to reach $99.9 \%$ of the stability value, mixing time can then be calculated using Equation (2).

$t_{\text {mix }}=x_{0}+6.91 d x$

Lag time is determined by the characteristics of the system, which is comprised of a fixed bed containing inert support and batch operation. Thus the tracer needs some time to cross the bed and to be detected by the probe, in this case the $\mathrm{pH}$ electrode. Hence, total mixing time $\left(\mathrm{t}_{\mathrm{Tmix}}\right)$ was defined as the sum of the lag time and the mixing time.

$\mathrm{t}_{\text {Tmix }}=\mathrm{t}_{0}+\mathrm{t}_{\text {mix }}$

After determination of the lag time, Microcal Origin $^{\circledR} 6.0$ software, which uses the LenvenbergMarquardt method, was used for sigmoid model fitting to the experimental data.

The reactor was designed to operate in fed-batch mode with a minimum volume of $2.5 \mathrm{~L}$ at the beginning and a maximum volume of $4.5 \mathrm{~L}$ at the end of operation. Thus, the reactor was characterized in relation to hydrodynamic behavior under the following conditions:

- Condition i: reactor at minimum capacity $(2.5 \mathrm{~L})$ characterizing start of fed-batch operation and $\mathrm{pH}$ electrode inserted into the foam bed.

- Condition ii: reactor at maximum capacity (4.5 L) characterizing end of fed-batch operation and $\mathrm{pH}$ electrode inserted into the foam bed.

- Condition iii: reactor at maximum capacity and $\mathrm{pH}$ electrode above the bed.

Assays for hydrodynamic characterization were performed in duplicate at 100, 200, 300 and $500 \mathrm{rpm}$ for both propeller types (turbine and helix). The bed consisted only of polyurethane foam with no biomass. The average values of the fit parameters were calculated afterwards.

Performance and stability were assessed in the ASBBR treatment of cheese whey at $30 \pm 1^{\circ} \mathrm{C}$ with concentrations of 500, 1000 and $2000 \mathrm{mgCOD} / \mathrm{L}$; an 8 -h cycle time and stirring at 200, 300 and $500 \mathrm{rpm}$. For each concentration studied in the first cycle the reactor was fed with $3 \mathrm{~L}$ cheese whey. In the remaining cycles $2 \mathrm{~L}$ wastewater were always discharged and fed with $1 \mathrm{~L}$ always remaining as residual volume. This residual volume allowed the polyurethane foam to be always immersed in the fedbatch operation, where the volume of $2 \mathrm{~L}$ was fed in 10 minutes.

Bicarbonate alkalinity supplementation was in accordance with the methodology proposed by Ratusznei et al. (2003), maintaining the $\mathrm{NaHCO}_{3} / \mathrm{COD}$ ratio at 0.5 . The inert support was inoculated with sludge obtained from a UASB reactor treating poultry slaughterhouse effluent.

Organic matter concentrations (COD) for filtered $\left(\mathrm{C}_{\mathrm{S}}\right)$ and unfiltered $\left(\mathrm{C}_{\mathrm{ST}}\right)$ samples, $\mathrm{pH}$, bicarbonate alkalinity (BA) and total volatile solids (TVS) were obtained in accordance with to the Standard Methods for Examination of Water and Wastewater (1995) for influent and effluent samples.

\section{RESULTS AND DISCUSSION}

The behavior of the hydrodynamic assays for the turbine and helix propellers is shown in Figure 2. The variations in $t_{0}, t_{\text {mix }}$ and $t_{T \text { mix }}$ with increasing rotation are shown in Figures 3 and 4 and in Tables 1 and 2 the average fit parameters of the proposed model, $\mathrm{t}_{0}, \mathrm{t}_{\text {mix }}$ and $\mathrm{t}_{\mathrm{Tmix}}$, are listed.

In a comparison of the different hydrodynamic assay conditions $(i, i i, i i)$ for the turbine propeller, the lag times for conditions $i$ and $i i$ were approximately close, and higher for condition iii. At $200 \mathrm{rpm}$ and higher the values of $\mathrm{t}_{0}, \mathrm{t}_{\text {mix }}$ and $\mathrm{t}_{\text {Tmix }}$ for conditions $i$ and $i i$ were close again. For the rotations tested condition iii showed higher mixing times than conditions $i$ and $i i$. In the assays with the helix propellers $t_{0}$ values were close under all conditions. At $300 \mathrm{rpm}$ and higher approximately no difference in mixing time for conditions $i i$ and $i i i$ was observed. Condition $i$ always had lower mixing times.

A comparison of the propellers showed that for condition $i$ at $200 \mathrm{rpm}$ and higher lag time values were close, whereas for mixing time this behavior was similar at $300 \mathrm{rpm}$ and higher. For condition $i$ lag time showed behavior identical to that for condition $i$, whereas mixing time for the helix 
propellers was higher at all rotations. For condition iii, in general, lag time values were the same. At 300 rpm and higher approximately no difference was seen between propellers for the mixing time.

Under all conditions tested the model adopted provided a good fit to the experimental data, showing that it was appropriate to represent and determine mixing time in the system. The turbine propeller showed similar mixing conditions in the bed at the beginning (volume $2.5 \mathrm{~L}$ ) and at the end of

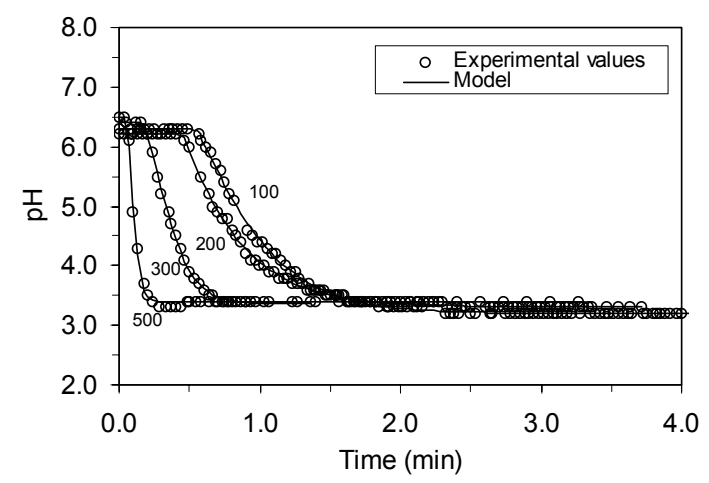

(a) the batch (volume $4.5 \mathrm{~L}$ ) (conditions $i$ and iii), with longer mixing times when homogenization of the top part of the reactor was taken into account (condition ii). For the helix propellers a shorter mixing time was found at the beginning of the batch (condition $i$ ) and similar values in both the bed and the top part of the reactor at the end (conditions $i i$ and $i i i)$. At low rotations performance of the turbine propeller was better, whereas at higher rotations mixing times were the same.

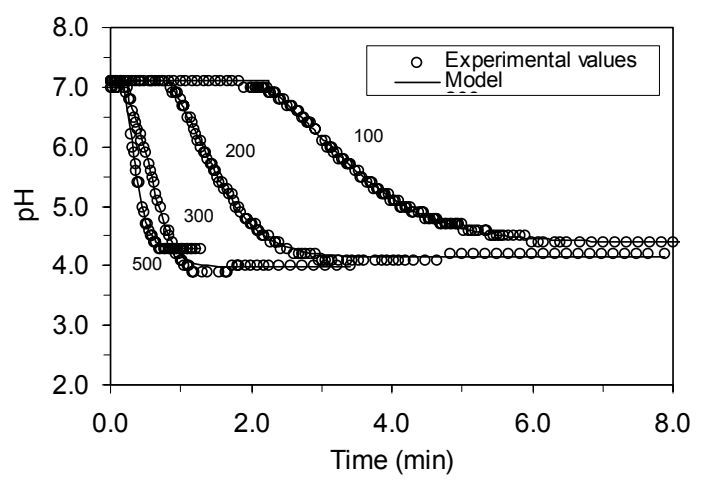

(b)

Figure 2: Variation in $\mathrm{pH}$ under Condition i for turbine (a) and helix propellers (b) as a function of rotation speed (rpm).

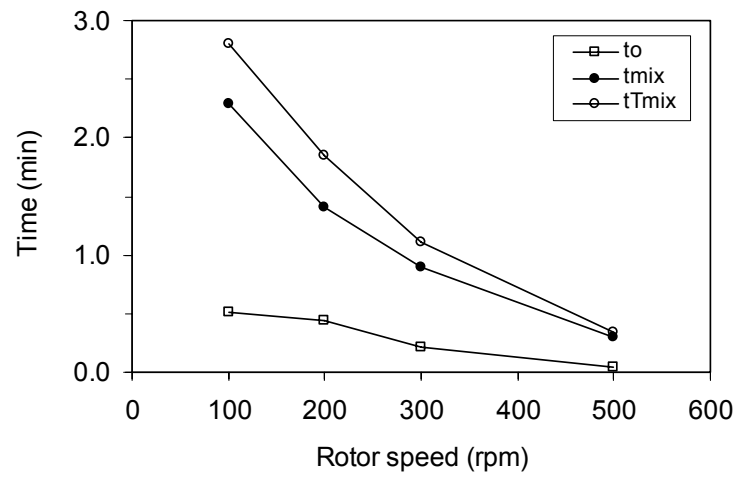

(i)

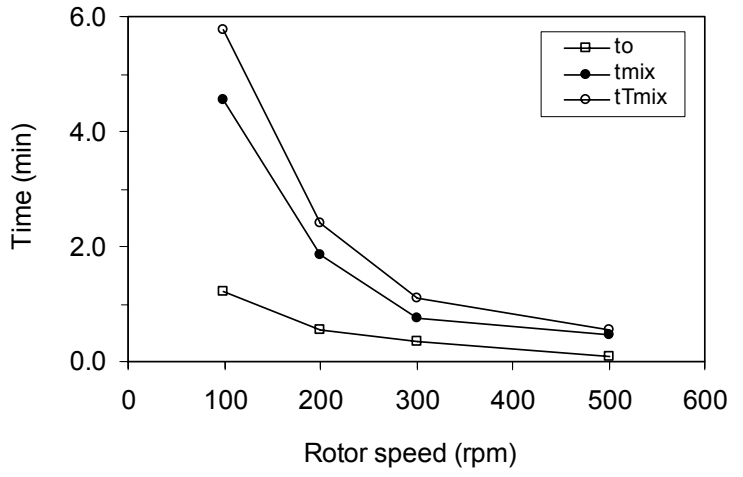

(ii)

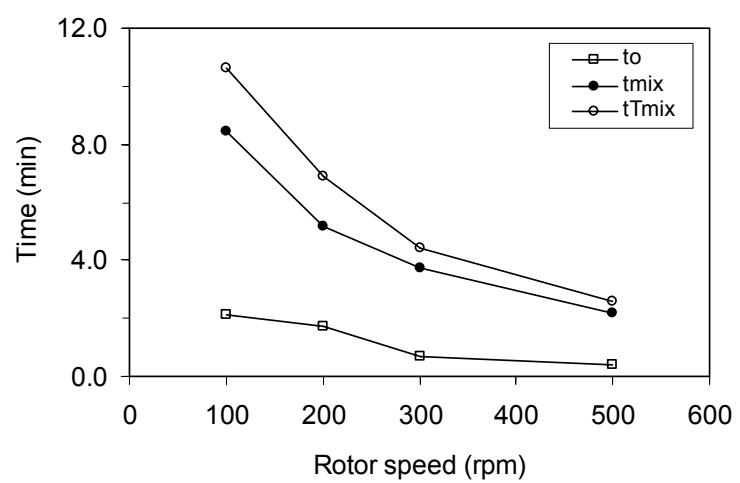

(iii)

Figure 3: Behavior of lag time $\left(\mathrm{t}_{0}\right)$, mixing time $\left(\mathrm{t}_{\text {mix }}\right)$ and total mixing time $\left(\mathrm{t}_{\mathrm{Tmix}}\right)$ for Conditions $i, i$ and $i i$ as a function of rotor speed for the turbine propeller. 


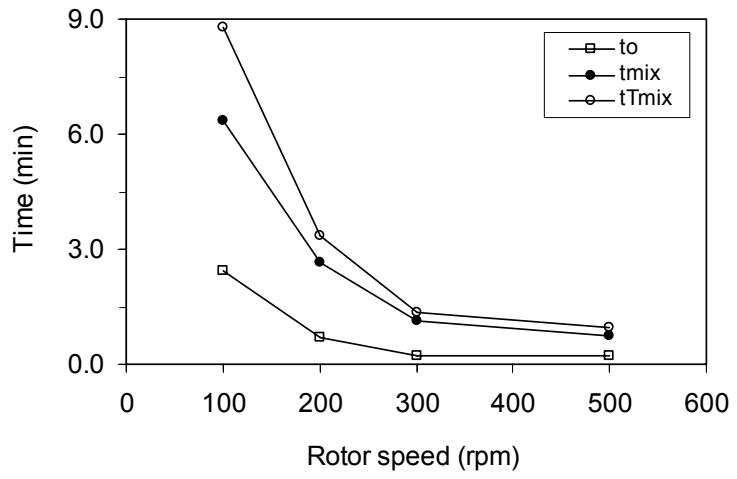

(i)

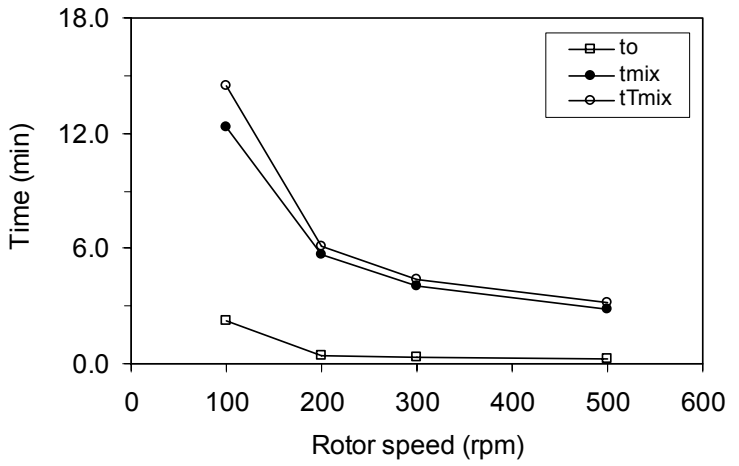

(ii)

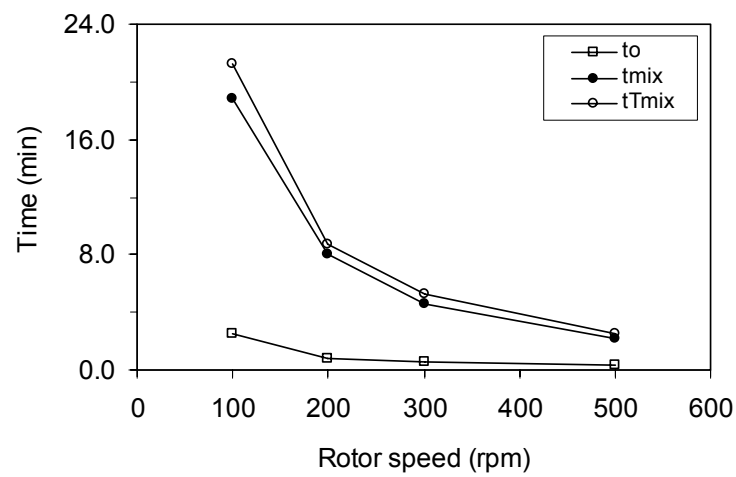

(iii)

Figure 4: Behavior of lag time $\left(\mathrm{t}_{0}\right)$, mixing time $\left(\mathrm{t}_{\text {mix }}\right)$ and total mixing time $\left(\mathrm{t}_{\mathrm{Tmix}}\right)$ for Conditions $i, i i$ and $i i$ as a function of rotor speed for the helix propellers.

Table 1: Average values of the adopted model parameters, lag time $\left(\mathrm{t}_{0}\right)$, mixing time $\left(\mathrm{t}_{\text {mix }}\right)$ and total mixing time $\left(t_{\text {Tmix }}\right)$ for the turbine propeller.

\begin{tabular}{|c|c|c|c|c|c|c|c|c|c|c|c|c|}
\hline \multirow{2}{*}{ Parameters } & \multicolumn{4}{|c|}{ Condition $i$} & \multicolumn{4}{|c|}{ Condition $i i$} & \multicolumn{4}{|c|}{ Condition iii } \\
\hline & 100 & 200 & 300 & 500 & 100 & 200 & 300 & 500 & 100 & 200 & 300 & 500 \\
\hline $\mathrm{A}_{1}$ & 21.5 & 42.0 & 7.3 & 6.9 & 7.8 & 7.7 & 6.6 & 6.9 & 6.5 & 10.2 & 10.8 & 15.4 \\
\hline $\mathrm{A}_{2}$ & 3.2 & 3.3 & 3.3 & 3.4 & 3.4 & 3.6 & 3.6 & 3.7 & 3.5 & 3.6 & 3.7 & 3.6 \\
\hline $\mathrm{x}_{0}$ & -0.54 & -0.72 & 0.18 & 0.08 & 0.68 & 0.23 & 0.23 & 0.14 & 1.63 & 0.25 & -0.19 & -0.25 \\
\hline $\mathrm{dx}$ & 0.41 & 0.31 & 0.10 & 0.03 & 0.56 & 0.24 & 0.08 & 0.05 & 0.99 & 0.71 & 0.57 & 0.35 \\
\hline$r^{2}$ & 0.998 & 0.990 & 0.998 & 0.992 & 0.997 & 0.988 & 0.984 & 0.991 & 0.993 & 0.989 & 0.994 & 0.995 \\
\hline $\mathrm{t}_{0}(\min )$ & 0.5 & 0.4 & 0.2 & 0.0 & 1.2 & 0.6 & 0.3 & 0.1 & 2.1 & 1.7 & 0.7 & 0.4 \\
\hline $\mathrm{t}_{\operatorname{mix}}(\min )$ & 2.3 & 1.4 & 0.9 & 0.3 & 4.5 & 1.9 & 0.8 & 0.5 & 8.5 & 5.2 & 3.7 & 2.2 \\
\hline $\mathrm{t}_{\mathrm{Tmix}}(\min )$ & 2.8 & 1.8 & 1.1 & 0.3 & 5.8 & 2.4 & 1.1 & 0.6 & 10.6 & 6.9 & 4.4 & 2.6 \\
\hline
\end{tabular}

Table 2: Average values of the adopted model parameters, lag time $\left(\mathrm{t}_{0}\right)$, mixing time $\left(\mathrm{t}_{\text {mix }}\right)$ and total mixing time $\left(t_{T m i x}\right)$ for the helix propeller.

\begin{tabular}{|c|c|c|c|c|c|c|c|c|c|c|c|c|}
\hline \multirow{2}{*}{ Parameters } & \multicolumn{4}{|c|}{ Condition $i$} & \multicolumn{4}{|c|}{ Condition $i i$} & \multicolumn{4}{|c|}{ Condition iii } \\
\hline & 100 & 200 & 300 & 500 & 100 & 200 & 300 & 500 & 100 & 200 & 300 & 500 \\
\hline $\mathrm{A}_{1}$ & 7.7 & 8.6 & 7.3 & 8.0 & 16.7 & 43.1 & 7.5 & 8.9 & 8.8 & 7.9 & 7.7 & 7.9 \\
\hline $\mathrm{A}_{2}$ & 4.3 & 4.2 & 4.0 & 4.2 & 5.7 & 5.4 & 5.2 & 5.2 & 5.4 & 5.4 & 5.3 & 4.9 \\
\hline $\mathrm{x}_{0}$ & 1.30 & 0.22 & 0.25 & 0.09 & -2.49 & -5.05 & 0.83 & 0.01 & 0.29 & 0.98 & 0.60 & 0.25 \\
\hline $\mathrm{dx}$ & 0.73 & 0.35 & 0.13 & 0.09 & 2.14 & 1.55 & 0.46 & 0.42 & 2.68 & 1.02 & 0.58 & 0.27 \\
\hline$r^{2}$ & 0.998 & 0.998 & 0.995 & 0.996 & 0.979 & 0.932 & 0.998 & 0.997 & 0.996 & 0.996 & 0.997 & 0.997 \\
\hline $\mathrm{t}_{0}(\mathrm{~min})$ & 2.4 & 0.7 & 0.2 & 0.2 & 2.2 & 0.5 & 0.4 & 0.3 & 2.5 & 0.8 & 0.6 & 0.4 \\
\hline $\mathrm{t}_{\operatorname{mix}}(\min )$ & 6.4 & 2.6 & 1.1 & 0.7 & 12.3 & 5.7 & 4.0 & 2.9 & 18.8 & 8.0 & 4.6 & 2.1 \\
\hline $\mathrm{t}_{\mathrm{T} \operatorname{mix}}(\min )$ & 8.8 & 3.4 & 1.4 & 0.9 & 14.5 & 6.1 & 4.4 & 3.2 & 21.3 & 8.8 & 5.2 & 2.5 \\
\hline
\end{tabular}


Figures 5, 6 and 7 show the values of COD removal efficiency, of bicarbonate alkalinity and of total volatile acid concentration under operation with turbine and helix propellers for cheese whey concentrations of $0.5 \mathrm{gCOD} / \mathrm{L}(I), 1.0 \mathrm{gCOD} / \mathrm{L}(I I)$ and $2.0 \mathrm{gCOD} / \mathrm{L}(I I I)$.

In the study of reactor behavior using a turbine propeller, the first phase consisted of adaptation of the biomass, where the system was operated for eight cycles with a cheese whey concentration of $0.5 \mathrm{gCOD} / \mathrm{L}$ and a rotation of $50 \mathrm{rpm}$. Next, the system was operated for eight cycles with a cheese whey concentration of $1.0 \mathrm{gCOD} / \mathrm{L}$ and a rotation of $200 \mathrm{rpm}$ showing stability and conversion efficiency higher than $80 \%$, with a maximum TVA concentration of a $56 \mathrm{mgHAc} / \mathrm{L}$. Subsequently, the system was operated with a cheese whey

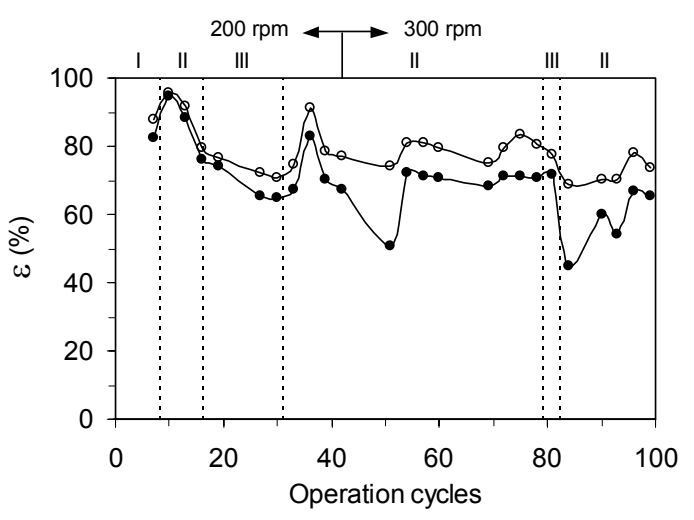

(a) concentration of $2.0 \mathrm{gCOD} / \mathrm{L}$ for 15 cycles, which occasioned an excessive increase in TVA requiring a reduction in cheese whey concentration to 1.0 $\mathrm{gCOD} / \mathrm{L}$ for 11 cycles, reducing COD and TVA concentrations.

Maintaining the cheese whey concentration at 1.0 $\mathrm{gCOD} / \mathrm{L}$ and increasing the rotation to $300 \mathrm{rpm}$, operating the system for 37 cycles, no significant variation in performance was observed, since organic matter conversion efficiency and acids production remained at stable values. Next, influent concentration was increased to $2 \mathrm{gCOD} / \mathrm{L}$, maintaining the rotation at $300 \mathrm{rpm}$ for three cycles, which caused excessive production of volatile acids, although COD removal efficiency was maintained. Thus, it was necessary to reduce the concentration to $1.0 \mathrm{gCOD} / \mathrm{L}$ with the system operating for 18 cycles.

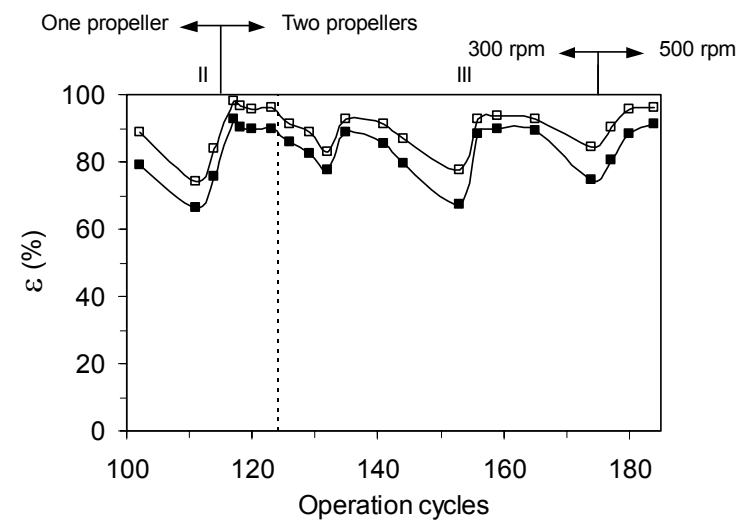

(b)

Figure 5: COD organic matter conversion efficiency for filtered $(O)$ and unfiltered samples $(\bullet)$ for turbine (a) and helix propellers (b).

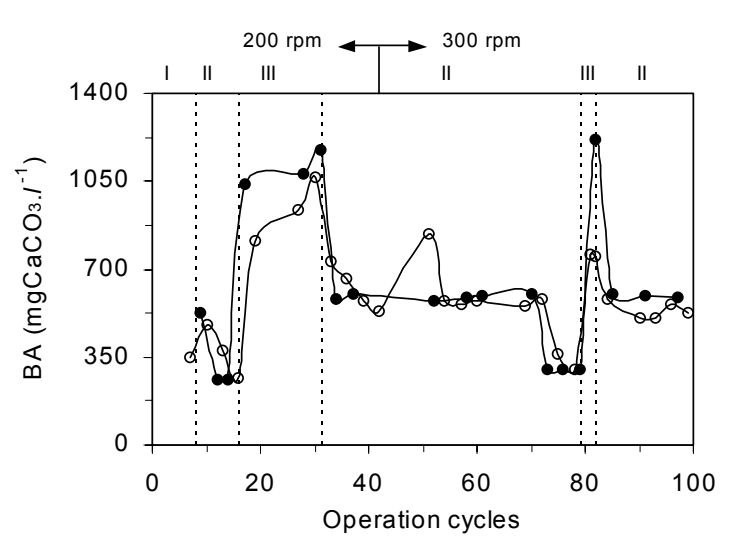

(a)

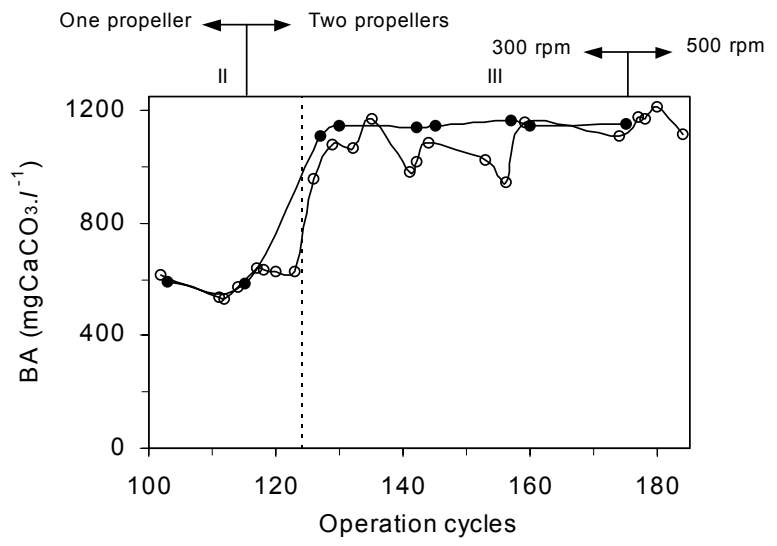

(b)

Figure 6: Bicarbonate alkalinity $(\mathrm{AB})$ in the influent $(\bullet)$ and in the effluent

(O) for turbine (a) and helix propellers (b). 


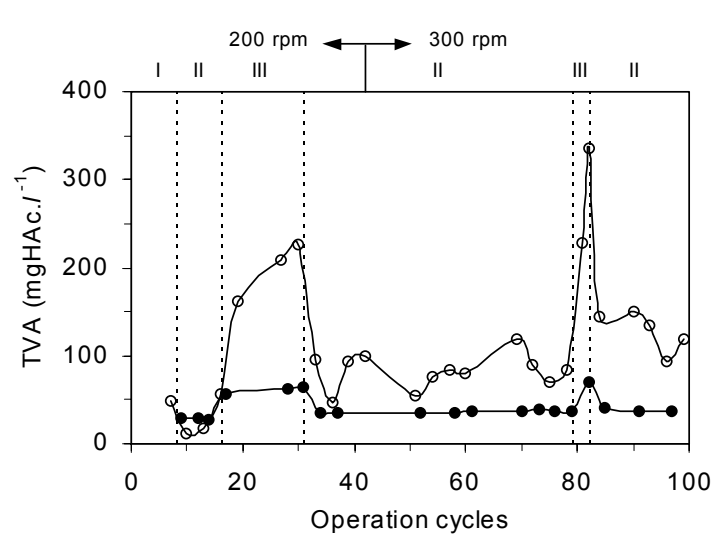

(a)

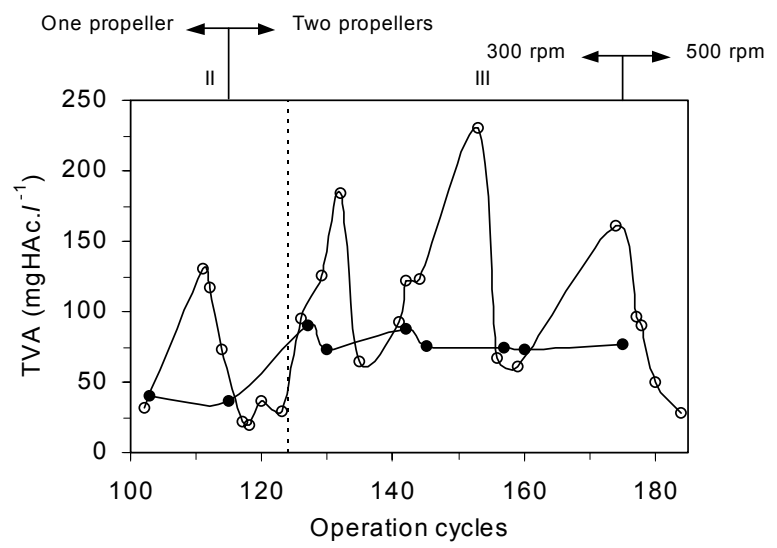

(b)

Figure 7: Total volatile acids (TVA) in the influent $(\bullet)$ and in the effluent for turbine (a) and helix propellers (b).

In the study of reactor behavior using the helix propellers, the biomass from the research with the turbine propeller was used in order to avoid the adaptation period of the biomass. Thus, starting at cycle 101, a helix propeller was used below the bed at $300 \mathrm{rpm}$, maintaining the cheese whey concentration at $1 \mathrm{gCOD} / \mathrm{L}$. The system operated for 15 cycles with average COD removal efficiencies higher than $75 \%$ and a TVA concentration below $130 \mathrm{mgHAc} / \mathrm{L}$.

In order to verify the effect of two helix propellers on the system, the reactor was operated for nine cycles under the same conditions as the previous, but another propeller was placed above the polyurethane foam bed. COD removal efficiency higher than $96 \%$ was obtained, with TVA values less than $40 \mathrm{mgHAc} / \mathrm{L}$. Next, cheese whey concentration was increased to $2 \mathrm{gCOD} / \mathrm{L}$, maintaining the rotation at $300 \mathrm{rpm}$, which resulted in an increase in TVA concentration and concomitant formation of polymer-like material in the reactor operated for nine cycles. After cleaning the system to remove this material, conversion efficiency was seen to increase and TVA concentration in the effluent reduced after operation for nine cycles. Next, efficiency decreased again with an increase in TVA concentration due to the presence of polymer-like material, requiring a new cleanup of the system. After cleaning the system was operated for 21 cycles.

To evaluate the hypothesis of improved mass transfer conditions with increasing rotation, influent concentration was maintained at $2 \mathrm{gCOD} / \mathrm{L}$ and rotation was increased to $500 \mathrm{rpm}$. Removal efficiency was significantly improved and total volatile acid concentration reduced after operation for nine cycles, indicating that this rotation is more appropriate for reactor operation. This improvement might be explained by the fact that, besides a better flow of the substrate across the bed provided by the helix propeller, the polymer formed accumulated less in the system due to faster movement, resulting in the discharge of material together with the effluent.

\section{CONCLUSIONS}

In general, the hydrodynamic study in the ASBR, containing immobilized biomass on polyurethane foam, indicated that the time necessary for homogenization of the reactor was negligible in relation to the cycle time, even at low rotor speeds for the two types of propellers tested. In virtue of the axial flow type, with the helix propellers homogenization was better than it was with the turbine propeller, despite requiring longer mixing times at low concentrations. Mixing time was similar for both types of propeller only at high rotations.

Results in the treatment of cheese whey with immobilized biomass showed the importance of propeller type not only for system homogenization (mixing time), but also for liquid flow through the bed, improving liquid-solid mass transfer rates (substrate-biomass) in the reactor. The low organic matter conversions obtained for the turbine propeller were very likely caused by the lower homogeneity between the upper part of the reactor (which contained only liquid) and the reactor bed; this hypothesis was confirmed by the operation results. The helix propellers were seen to provide better flow conditions for the proposed configuration, evidenced by the improved COD conversion and by the lower production of total volatile acids. 


\section{ACKNOWLEDGMENTS}

This study was supported by the Fundação de Amparo à Pesquisa do Estado de São Paulo (FAPESP, São Paulo, Brazil, process n $n^{\circ}$ 02/06154-5). We acknowledge the assistance of Dr. Baltus C. Bonse in the revision of this paper.

\section{NOMENCLATURE}

\section{Symbols}

BA bicarbonate alkalinity

$\mathrm{C}_{\mathrm{I}} \quad$ unfiltered substrate concentration in the influent,

$\mathrm{C}_{\mathrm{S}} \quad$ filtered substrate concentration in the effluent

$\mathrm{C}_{\mathrm{ST}} \quad$ unfiltered substrate concentration in the effluent

TVA, total volatile acid concentration

$\varepsilon_{\text {ST }} \quad$ substrate removal efficiency considering non-filtered substrate concentration

$\varepsilon_{\mathrm{SF}} \quad$ substrate removal efficiency considering filtered substrate concentration

\section{Abbreviations}

ASBR anaerobic sequencing batch reactor

COD chemical oxygen demand

UASB upflow anaerobic sludge blanket

$\mathrm{mgCaCO} / \mathrm{L}$
$\mathrm{mgCOD} / \mathrm{L}$
$\mathrm{mgCOD} / \mathrm{L}$
$\mathrm{mgCOD} / \mathrm{L}$
$\mathrm{mgHAc} / \mathrm{L}$
$\%$
$\%$

$\%$

\section{REFERENCES}

Angenent, L .T. and Dague, R. R., A Laboratoryscale Comparison of the UASB and ASBR Processes. 50th Purdue Industrial. Wastewater Conference Proceedings, Ann Arbor Press, Chelsea, Michigan, USA, p. 365-377 (1995).

Cubas, S. A., Pinho, S. C., Foresti, E., Rodrigues, J.A.D., Ratusznei, S.M. and Zaiat, M., Effects of Solid-Phase Mass Transfer on a Stirred Anaerobic Sequencing Batch Reactor Containing Immobilized Biomass. VII Taller y Simposio Latinoamericano Sobre Digestión Anaerobia, Mérida, Yucatan, México, p. 229-236 (2002).

Dague, R. R., Habben, C. E. and Pidaparti, S.R., Initial Studies on the Anaerobic Sequencing Batch Reactor. Water Science and Technology,

26, 2429-2432 (1992).

Droste, R. L. and Massé, D. I., Anaerobic Treatment in Sequencing Batch Reactor. International Symposium on Technology Transfer, Salvador, Bahia, Brasil, p.353-363 (1995).

Dugba, P. N. and Zhang, R., Treatment of Dairy Wastewater with Two-Stage Anaerobic Sequencing Batch Reactor Systems -Thermophilic versus Mesophilic Operations. Bioresource Technology, 68, 225-233 (1999).

Ndon, U. J. and Dague, R. R., Ambient Temperature Treatment of Low Strength Wastewater Using Anaerobic Sequencing Batch Reactor. Biotechnology Letters, 19, 319-323 (1997).

Pinho, S. C., Cubas, S. A., Ratusznei, S.M., Rodrigues, J.A.D., Foresti, E. and Zaiat, M., Influence of the Agitation Rate on the Treatment of Partially Soluble Wastewater in Anaerobic Sequencing Batch Reactor Containing Immobilized Biomass. VII Taller y Simposio Latinoamericano Sobre Digestión Anaerobia, Mérida, Yucatan, México, p. 103-106 (2002).

Ratusznei, S. M., Rodrigues, J. A. D., Camargo, E. F. M., Zaiat, M. and Borzani, W., Feasibility of a Stirred Anaerobic Sequencing Batch Reactor Containing Immobilized Biomass for Wastewater Treatment. Bioresource Technology, 75, 127-132 (2000).

Ratusznei, S. M., Rodrigues, J. A. D., Camargo, E.F.M., Zaiat, M. and Borzani, W., Influence of Agitation Rate on the Performance of a Stirred Anaerobic Sequencing Batch Reactor Containing Immobilized Biomass. Water Science and Technology, 44, 305-312 (2001).

Ratusznei, S. M., Rodrigues, J. A. D. and Zaiat, M., Operating Feasibility of Anaerobic Whey Treatment in a Stirred Sequencing Batch Reactor Containing Immobilized Biomass. Water Science and Technology, 48, 179-186 (2003).

Standard Methods for the Examination of Water and Wastewater, 19th ed, American Public Health Association/American Water Works Association/ Water Environment Federation, Washington, D.C., USA (1995).

Zaiat, M., Rodrigues, J. A. D., Ratusznei, S.M., Camargo, E.F.M. and Borzani, W. Anaerobic Sequencing Batch Reactors for Wastewater Treatment: A Developing Technology. Applied Microbiology and Biotechnology, 55, 29-35 (2001).

Zhang, R., Yin, Y., Sung, S. and Dague, R. R., Anaerobic Treatment of Swine Waste by the Anaerobic Sequencing Batch Reactor. 51st Purdue Industrial Waste Conference Proceedings, Ann Harbor Press, Chelsea, Michigan, USA, p. 315-320 (1996). 